\title{
Physical activity is also an allergy prevention measure
}

Hong Kong Med J 2016;22:514

DOI: 10.12809/hkmj165036

To the Editor-I read with interest the excellent article "Guidelines for allergy prevention in Hong Kong" by Chan et $\mathrm{al}^{1}$ in the June 2016 issue of the Hong Kong Medical Journal. I agree with the authors but there is one lifestyle aspect worth mentioning. Recent studies show that children and adults with a low level of physical activity have a significantly increased risk for asthma and eczema. ${ }^{2-5}$ Regular aerobic activity such as walking, cycling, running, playing ball, or swimming has the potential to improve exercise capacity, bronchial hyperresponsiveness and lung function, and reduces serum proinflammatory cytokines (eg interleukin-4 and -6 , and monocyte chemoattractant protein 1 ). In my opinion the timeless rule "SIT LESS, MOVE MORE, EVERY DAY!" should also be added to the allergy prevention measures in Hong Kong.

\section{Martin Hofmeister *, PhD}

Consumer Centre of the German Federal State of Bavaria Department Food and Nutrition Mozartstraße 9, D-80336 Munich Germany

\section{* Corresponding author: hofmeister@vzbayern.de}

\section{References}

1. Chan AW, Chan JK, Tam AY, Leung TF, Lee TH. Guidelines for allergy prevention in Hong Kong. Hong Kong Med J 2016;22:279-85.

2. Strom MA, Silverberg JI. Associations of physical activity and sedentary behavior with atopic disease in United States children. J Pediatr 2016;174:247-53.e3.

3. Lochte L, Nielsen KG, Petersen PE, Platts-Mills TA. Childhood asthma and physical activity: a systematic review with meta-analysis and Graphic Appraisal Tool for Epidemiology assessment. BMC Pediatr 2016;16:50.

4. Guldberg-Møller J, Hancox B, Mikkelsen D, Hansen HS, Rasmussen F. Physical fitness and amount of asthma and asthma-like symptoms from childhood to adulthood. Clin Respir J 2015;9:314-21.

5. Silverberg JI, Greenland P. Eczema and cardiovascular risk factors in 2 US adult population studies. J Allergy Clin Immunol 2015;135:721-8.e6.

\section{Authors' reply}

To the Editor-We thank Dr Hofmeister for highlighting an emerging area in allergy prevention. The evidence for the association of lack of physical activity with allergic diseases in both adults and children is interesting ${ }^{1-4}$ but the results were obtained mainly through population-based crosssectional studies. Although there may be a true association between a decrease in physical activity and more atopic tendencies, one cannot exclude reverse causality of decreased physical activity in these groups of atopic patients, for instance an exacerbation of eczema after sweating; heat and dermatographic stimulation; or shortness of breath in exercise-induced asthma. It is essential now to conduct prospective studies to test the hypothesis when some of the confounding factors that may discourage atopic patients to exercise are tightly controlled. Of course, we agree that adequate exercise helps to control body weight that is known to be associated with asthma and eczema as mentioned in the guidelines..$^{5-7}$ We will continue to review the important area of physical activity in relation to allergy and will update our guidelines accordingly.

${ }^{1}$ Alson WM Chan *, FHKCPaed, FHKAM (Paediatrics)

2 June KC Chan, RD (USA), MSC

${ }^{1}$ Alfred YC Tam, FHKCPaed, FHKAM (Paediatrics)

${ }^{3}$ TF Leung, MD, FHKAM (Paediatrics)

${ }^{2}$ TH Lee, ScD (Cantab), FRCP (Lond)

${ }^{1}$ Department of Paediatrics and Adolescent Medicine, The University of Hong Kong, Pokfulam, Hong Kong

${ }^{2}$ Allergy Centre, Hong Kong Sanatorium \& Hospital, Happy Valley, Hong Kong

${ }^{3}$ Department of Paediatrics, The Chinese University of Hong Kong, Shatin, Hong Kong

* Corresponding author: awmc@hku.hk

\section{References}

1. Silverberg JI, Song J, Pinto D, et al. Atopic dermatitis is associated with less physical activity in US adults. J Invest Dermatol 2016;136:1714-6.

2. Parrish AM, Okely AD, Stanley RM, Ridgers ND. The effect of school recess interventions on physical activity: a systematic review. Sports Med 2013;43:287-99.

3. Eijkemans M, Mommers M, Draaisma JM, Thijs C, Prins $\mathrm{MH}$. Physical activity and asthma: a systematic review and meta-analysis. PLoS One 2012;7:e50775.

4. Kilpeläinen M, Terho EO, Helenius H, Koskenvuo M. Body mass index and physical activity in relation to asthma and atopic diseases in young adults. Respir Med 2006;100:1518-25.

5. Chen YC, Dong GH, Lin KC, Lee YL. Gender difference of childhood overweight and obesity in predicting the risk of incident asthma: a systematic review and meta-analysis. Obes Rev 2013;14:222-31.

6. Rzehak P, Wijga AH, Keil T, et al. Body mass index trajectory classes and incident asthma in childhood: results from 8 European Birth Cohorts-a Global Allergy and Asthma European Network initiative. J Allergy Clin Immunol 2013;131:1528-36.

7. Mitchell EA, Beasley R, Björkstén B, Crane J, GarcíaMarcos L, Keil U; ISAAC Phase Three Study Group. The association between BMI, vigorous physical activity and television viewing and the risk of symptoms of asthma, rhinoconjunctivitis and eczema in children and adolescents: ISAAC Phase Three. Clin Exp Allergy 2013;43:73-84. 